DOI: https://doi.org/10.31933/dijdbm.v2i2 Received: 9 December 2020, Revised: 15 January 2021, Publish: 3 March 2021

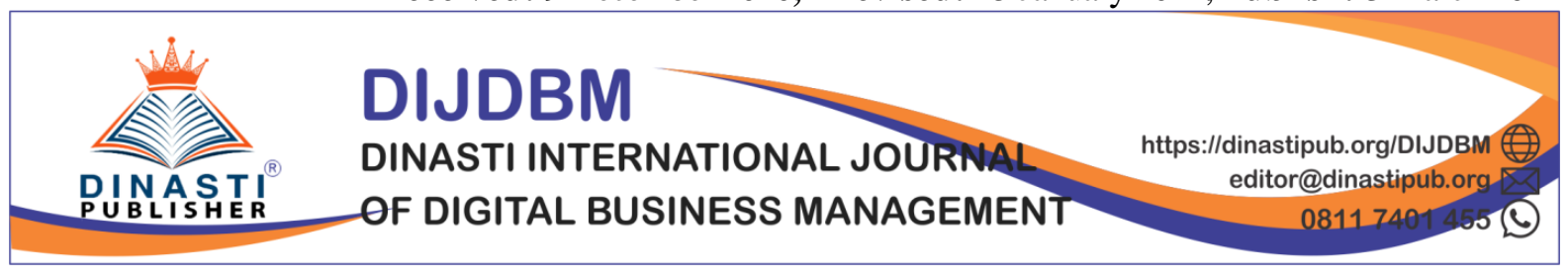

\title{
SYARIAH BANK EMPLOYEE PERFORMANCE MODEL OF PT. BANK SYARIAH AL SALAAM REGIONAL JAKARTA AND DEPOK
}

\author{
Zainuri Zainuri ${ }^{1}$, Muhammad Havidz Aima ${ }^{2}$, Muhammad Ali Iqbal ${ }^{3}$, Ngadino Surip ${ }^{4}$ \\ ${ }^{1)}$ Magister Management, Mercu Buana University, igho.syailendra@gmail.com \\ ${ }^{2}$ Magister Management, Mercu Buana University, havidz.aima@mercubuana.ac.id \\ ${ }^{3)}$ Magister Management, Mercu Buana University, ali.iqbal@mercubuana.ac.id \\ ${ }^{4)}$ Magister Management, Mercu Buana University, dinosurip@gmail.com
}

Corresponding Author: Zainuri

\begin{abstract}
This study aims to examine the prophetic leadership and organizational commitment mediated by the motivation that affects employee performance, namely the employee performance of PT Bank Syariah Al Salaam Jakarta and Depok Regional. The research method uses a quantitative approach, with data collection using primary data, secondary data from Personnel Management and library research, primary data using all employees at PT Bank Syariah Al Salaam as many as 80 respondents, from all Jakarta and Depok Regional Divisions. Data collection techniques using interviews and questionnaire instruments. The questionnaire survey instrument was delivered randomly to employees of PT Bank Syariah Al Salaam. Data were analyzed using structural equation modeling (SEM) with the Smart PLS3.0 software program. to test the significance of prophetic leadership and organizational commitment affecting employee performance and mediated by motivation. The results showed that prophetic leadership, organizational commitment and motivation have a significant positive effect on employee performance, either partially or simultaneously. Prophetic leadership as the most important factor influencing employee performance. The managerial implication is that the organization or leader must develop a harmonious work culture and motivation for employees to achieve their best performance. This study reveals that organizational commitment, Prophet Leadership and motivation have a significant positive effect on performance, both partially and simultaneously. Besides that, the motivation partially mediate variable of the Prophet Leadership variable and organizational commitment on performance and has a significant effect.
\end{abstract}

Keywords: Prophetic leadership, organizational commitment, motivation, employee performance

\section{INTRODUCTION}

Organizational commitment and prophetic leadership can have an impact on increasing the achievement of organizational performance, just as ethical leaders increase organizational pride and loyalty. In an organization, there is the possibility of having an indirect impact on the increase of commitment or performance of members to the organization, when leadership is unable to emphasize to its members about their relationship and contribution to the success of the organization and unable to build positive relationships with members of the organization. Organizational goals may not be achieved if its members do not want to contribute to the achievement of organizational goals, when the organization does not help members achieve its goals. 
PT. Al Salaam Syariah Bank is one of the sharia financing banks as a financial service financing institution that applies management to the prophetic leadership and high organizational commitment. Where it is not only about achieving a high portfolio in running its business but also balancing the principles of the world and the hereafter, because of working and living are parts of worship. To become one of the pioneers of Islamic banking in Indonesia which applies sharia principle.

Business performance is inseparable from employee performance which comes from human resources itself, where it is important to understand the main factors that affect employee performance compared to understabd the impact or effect on the employee's own performance. The managerial pattern applied by the company has an impact on the increase and decrease of sales performance received by the company within a period of 3 (three) years starting from 2016 to 2018.

The business performance achievement of PT Bank Syariah Al Salaam has not been fully performed properly, even tended to decline for the achievements which have been set by the company over the last three years. In performing the work process in 2016 was amounting to Rp. $6,516,152$ with a value percentage was $65 \%$ of the target set by the company, but in the following year there was a gradual decline. Another decline was occurred in the achievement of the UMKM target which in 2017 was reached 54\%, decreased in 2017 and 2018 to $65 \%$, it should be expected that this achievement will increase every year. The decline in business performance, in this case the productivity of employees in the Marketing Division in the process of marketing activities decreased every year from $70 \%$ (2016) to $60 \%$ (2017) and to 50\% (2018) this data was obtained based on direct interviews with Business Directors and Division Heads. Marketing), marketing activities are routine activities performed by employees in increasing their performance each year, especially in increasing their portfolios. In addition, the active role of employees in enforcing discipline tends to decline in 2017 and 2018 data.

Table 1. PT Bank Syariah Al Salaam Sales Permormance Trends

\begin{tabular}{ccc}
\hline $\begin{array}{c}\text { Sales Performance } \\
\text { Trends (Year) }\end{array}$ & $\begin{array}{c}\text { Increase / Reduction } \\
\text { (In Million Rp.) }\end{array}$ & Percentage (RBB) \\
\hline 2016 & Rp6.516.152,- & $65 \%$ \\
\hline 2017 & Rp5.427.422,- & $54 \%$ \\
\hline 2018 & Rp9.997.621,- & $65 \%$ \\
\hline \multicolumn{3}{c}{ Source: Managed by researcher (2019) }
\end{tabular}

\section{Research Objectives and Statements}

The purpose of this research is to develop a model for measuring the decisions in prophetic leadership and organizational commitment in getting the best performance of employees through motivation mediation. This research includes the following theoretical objectives:

1. To Introduce the treatment decision model of employee performance.

2. To determine the relationship between prophetic leadership and organizational commitment toward employee performance through motivational mediation.

3. To identify and measure several indicators related toward prophetic leadership and employee performance.

Based on the purpose of writing above, the study defines the question formulation as follows:

1. Does prophetic leadership have a significant effect on motivation? 
2. Does organizational commitment have a significant effect on motivation?

3. Does prophetic leadership have a significant effect on employee performance?

4. Does organizational commitment have a significant effect on employee performance?

5. Does motivation have a significant effect on employee performance?

6. Do prophetic leadership and organizational commitment together have a significant effect on motivation?

7. Do prophetic leadership and organizational commitment have a significant effect on motivation and their implications simultaneously have a significant effect on employee performance?

8. Does motivation significantly mediate both prophetic leadership and organizational commitment to employee performance?

\section{LITERATURE REVIEW \\ Prophetic Leadership}

In prophetic leadership, leadership is spiritualistic, since it is closely related to divine values (Zuhdi, 2014). These messengers put a cor of their leadership on the truth which comes from God in guiding, serving, enlightening, and making changes. The leadership of these Messengers are from the nature of humans as representatives of God (caliph) who are given the authority to lead and maintain His earth and everything in it from the damage. The meaning of caliph in humans as a leader is implemented in leadership characters who always adhere to the conscience (Zuhdi, 2014).

Since the focus of the study is on the prophetic of Islam, leadership has two main roles, namely: 1) a leader as a servant (servant leader), a public servant, in charge of preserving the welfare of the community and guiding them to goodness, 2) a leader as a protector (guardian leader), in charge of protecting the community from threats and as a protector that promotes god awareness, as well as justice, trust and integrity. In Islamic prophetic leaders are leaders who have personality and characteristics that are included in the dimensions of the prophetic leadership variable, namely siddiq (honest with integrity), amanah (trustworthy and responsible), fathanah (intelligent, quality, professional), tabligh (communicative and visionary). (Antonio, Budiharto and Himam, 2007) the personalities and characteristics above are the dimensions that connect to prophetic leadership performance.

\section{Organizational Commitment}

There are three dimensions of organizational commitment measurements according to Allen and Meyer (1991), namely: 1) affective commitment, which refers to the emotional relationship of members to the organization. People with a high level of affective commitment have a desire to stay in the organization because they support the goals of the organization and willing to help them achieve the goals. Affective commitment occurs when an employee wants to be part of the organization because of an emotional attachment. 2) Continuance commitment, which refers to the employee's desire to stay in the organization because of the calculation of profit and loss where the perceived economic value of staying in an organization is compared to leaving the organization. The longer they stay with their organization, the more they are afraid of losing what they have invested in the organization. This commitment leads to the tendency of employees not to leave the organization. The investment that employees already have are in the form of time, their effort in doing work, developing friendships with fellow colleagues, certain skills needed by the organization, and compensation that can reduce employees to other external opportunities (Jaros, Jermier, Koehler and Sincich, 1993). Continuous commitment occurs when employees stay in an 
organization because they need a salary and other benefits, because they need to. Normative commitment refers to the feelings of employees where they feel obliged to remain in the organization because they personally feel they have a moral responsibility towards the organization. This normative commitment occurs from the employee's self-values.

\section{Motivation}

Motivation is an activity that encourages workers or employees to do their best in carrying out their duties because they believe with the success of the organization in achieving its goals and objectives, the personal interest of the members of the organization will also be maintained. Motivation is a variety of behavior shown on the target with the effort level of a person makes in pursuing a certain goal. According to Thoha (2012: 177) motivation is the desire to achieve several goals or incentives for someone to carry out activities to achieve their goals.

"Three Needs" Motivation Theory. This theory was stated by McCleland, he argues that a person will have high motivation if they are based on "Need for Achievement" (nAch), "Need for Affinity" (nAff), and "Need for Power" (nPo). The following is an explanation that makes three needs a dimension of motivation:

1. Need for Achievement (the necessity for achievement) means that a person always wants to be seen as successful person in life, with success he has indeed all his needs will be fulfiled. The success also able to be applied in a household life.

2. Need for Affiliation (The necessity for affiliation) means that everyone has a need for a friendly environment and working together in organizations. The need for affiliation will make a person tend to eliminate the atmosphere that arise the potential of competition, but this certainly will not hinder one's success at work because certainly good skills in team working is one of the gauge factors for a person is able to work well or not.

3. Need for Power (the necessity for authority) means that a person has a necessity to influence others, and tries to dominate others. People with high nPo will tend to be less concerned with jobs that do not increase the possibility of expanding the power, and the possibility of being able to influence others.

\section{Employee Performance}

Mangkunegara (2011: 67) defines performance (work performance) as follows: "Performance is the result of work both in quality and quantity achieved by an employee in performing his duties in accordance with the responsibilities given to him". Meanwhile Bernardin and Russel in Hasibuan (2011: 379), said that "Employee performance depends on ability, work effort and employment opportunities assessed from output". Timpe (2011: ix), argues that performance (work performance) is: "The level of individual performance, namely the desired results of individual behavior.

Donnelly, Gibson and Ivancevich in Rivai and Sagala (2014: 25) state that performance refers to the level of success in udertaking tasks and the ability to achieve the stated goals. Performance is stated as good and successful if the desired goals are achieved well. Hersey and Blanchard (2011: 179) define performance as the results that have been achieved by someone using certain media. This definition emphasizes that an employee cannot succeed in achieving his performance without the help of a media in the form of other means that affect him both intrinsically and extrinsically.

A person's performance can be influenced by internal factors and external factors, namely: 
1. Internal factor

Internal factor appears from the employee itself, such as attitudes, behavior, and abilities of employees which affect the daily performance of employees.

2. External Factor

External factor originates from the employee environment. This factor can affect the skills and motivation of employees.

PT Bank Syariah Amal Salman, the implementation of current employee performance is coring on key performance indicators that are assessed directly through their superiors according to the performance every 6 months.

Employee Performance Target (EPT) assessment covers the aspects of quantity, quality, time, and or in accordance with the personality, characteristic, and types of activities in each work unit. Quantity aspects include the percentage of output realization divided by the output target. Quality aspect is the realization percentage of quality per quality target. The evaluation aspect of the percentage of realization time is divided by the target time. The cost aspect is the percentage of the cost plan divided by the target cost. Each agency in preparing and setting technical standards for activities in accordance with the personality, characteristic, types of activities, and their respective task necessity. The assessment of work behavior includes aspects: service orientation, integrity, commitment, discipline, cooperation, and leadership.

From the explanation above, performance limit can be lifted up as a result of one's work where success can be assessed through the timeliness of completing work, the amount of work completed (quantity) and the quality of the work.

\section{Research model and hypotheses Research model}

From the explanation above, the research model developed in this journal is as shown in Figure 1. Prophetic leadership and organizational commitment as independent variables will affect motivation as a mediating variable. In addition, Prophetic Leadership and Organizational Commitment will affect employee performance as the dependent variable. Figure 2 below provides an overview of the research model.

Figure 1. Assessment Model

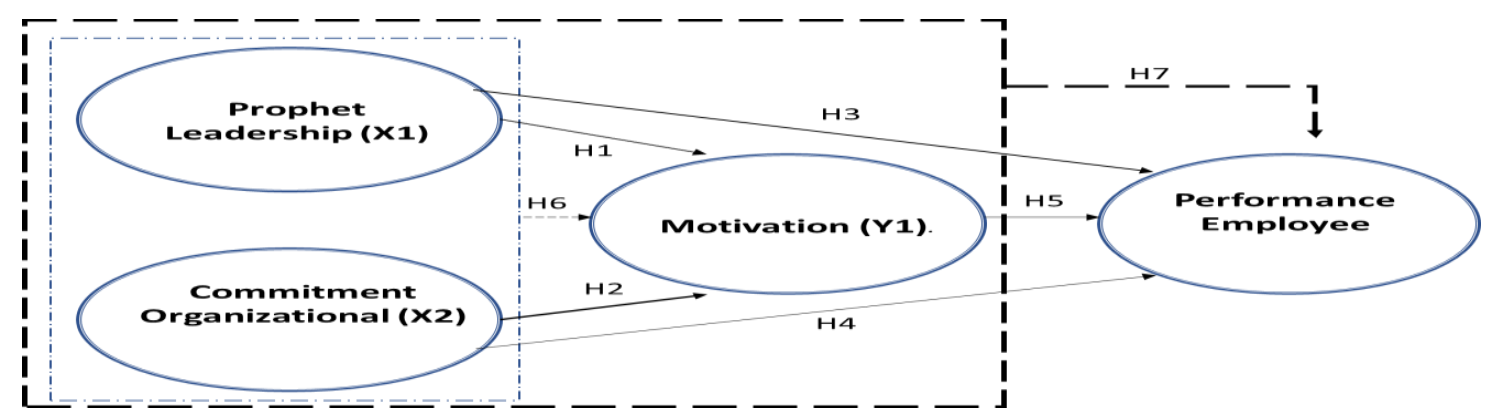

\section{Hypothesis}

Based on literature research and interview, the results of previous research and the above models, the hypothesis proposed are as follows:

H1: Prophetic leadership has a significant effect on motivation. 
H2: Organizational commitment has a significant effect on motivation.

H3: Prophetic leadership has a significant effect on employee performance.

H4: Organizational commitment has a significant effect on employee performance.

H5: Motivation has a significant effect on employee performance.

H6: Prophetic leadership and organizational commitment together have a significant effect on motivation.

H7: Prophetic leadership and Organizational Commitment have a significant effect on motivation and

the implication together has a significant effect on employee performance

H8: Motivation significantly mediates Prophetic Leadership and Organizational Commitment to employee performance.

\section{RESEARCH METHODS}

This research model uses quantitative statistical analysis using survey method with the aim of understanding, explaining and analyzing the relationship between independent variables (exogenous variables), namely Prophetic Leadership (X1) and Organizational Commitment (X2) with the dependent variable (endogenous variable), namely Motivation (Y1), and employee performance (Y2). This type of research in research using descriptive quantitative methods.

The quantitative method is performed by delivering questionnaires to respondents who are assigned the stages of pre-survey activities, survey research model formation, confirmatory research, and data analysis (Neuman, 2006). The pre-survey was performed by distributing questionnaires containing preliminary closed questions on a 5-point Likert scale to 30 employees of PT Bank Syariah Al Salaam. Furthermore, to conduct the test, it was performed by distributing questionnaires to 80 respondents all employees of PT Bank Syariah Al Salaam.

This research uses Partial Least Square (PLS) analysis technique, which using SmartPLS software runs on computer media.

PLS (Partial Least Square) is a variant-based Structural Equation Model (SEM) analysis that simultaneously able to perform measurement testing model and structural testing model. The measurement model is used to test the validity and reliability, while the structural model is used for the causality test (hypothesis testing with predictive models (Ghozali, 2016).

\section{FINDING AND DISCUSSION}

This research was conducted through analysis of the measurement model first, in order to find its validity and reliability, then followed by structural model analysis.

\section{Analysis of the outer model (measurement model)}

This analysis was conducted to find the validity and reliability of the indicators used to measure the latent variables. In this analysis, the convergent validity test was carried out beforehand. Furthermore, the discriminant validity test was performed. To test the validity of the indicators, the loading factor value $>0.5$ is declared valid and usable. The results of this study are shown in Figure 2. 


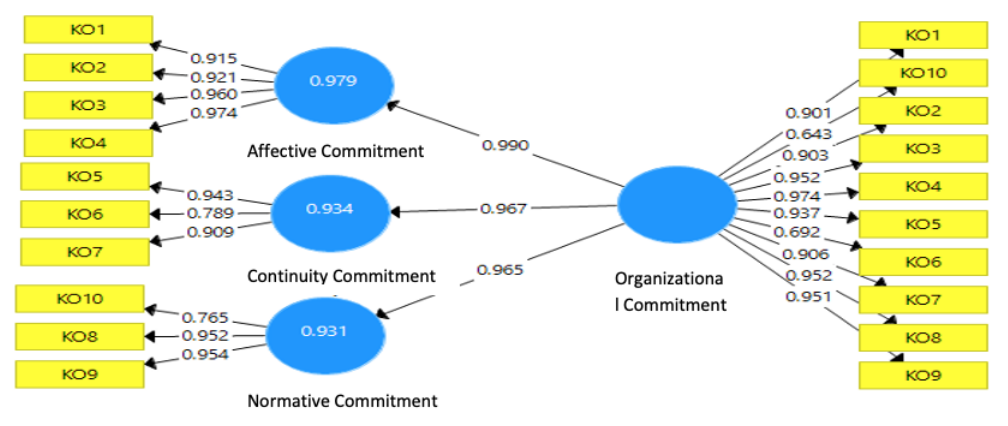

Figure 2: Measurement Model Calculation Result (Outer Model) Prophetic leadership Variable Source : Smart PLS 3.2.8 Version

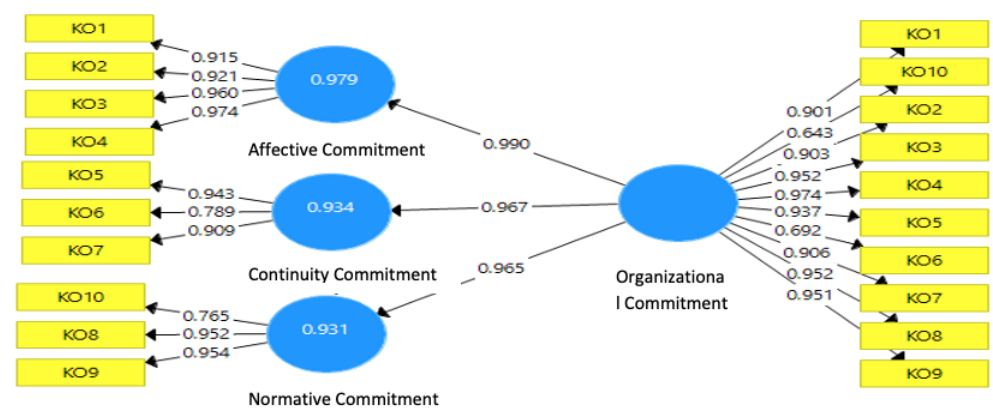

Figure 3 : Measurement Model Calculation Result (Outer Model) Organiztional Commitment Variable Source : Smart PLS 3.2.8 Version

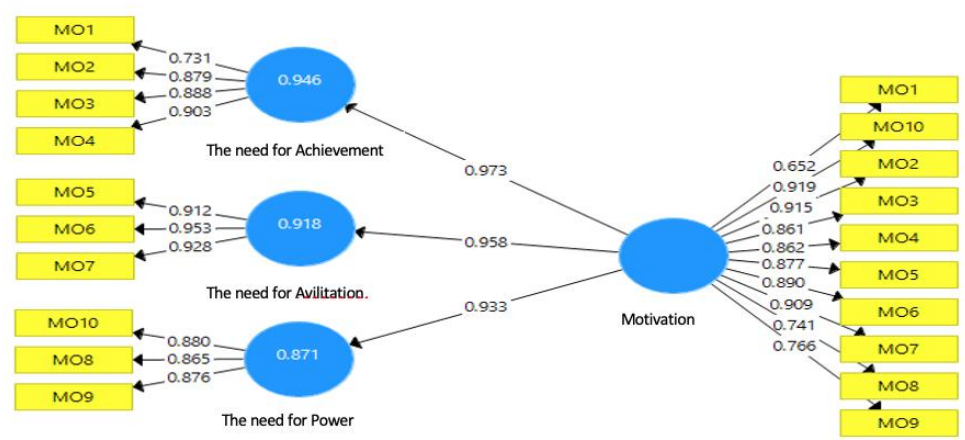

Figure 4 : Measurement Model Calculation Result (Outer Model) Motivation Variable Source : Smart PLS 3.2.8Version 


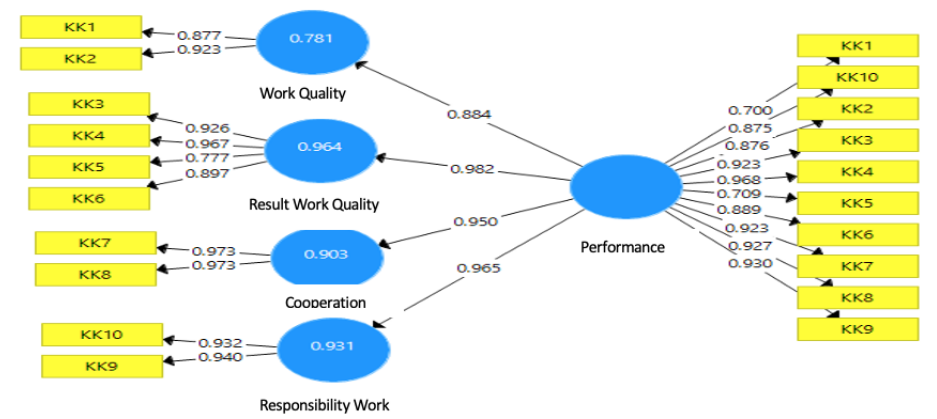

Figure 5 : Measurement Model Calculation Result (Outer Model) Performance Variable Source : Smart PLS 3.2.8 Version

From the picture above, can be seen that the indicators of these variables are all with a value> 0.5 which means that they are valid and can be usable. Furthermore, an analysis of the Average Variance Extracted value is carried out. AVE value is said to be good if it has a value> 0.5. The result of the study on the AVE value are shown in Table 1.

Table 2 Average Variance Extracted (AVE) Variable Value

\begin{tabular}{cc}
\hline V Variable & Average Variance Extracted (AVE) Score \\
\hline Prophetic Leadership & 0.769 \\
Organizational Commitment & 0.768 \\
Motivation & 0.788 \\
Performance & 0.709 \\
\hline
\end{tabular}

Table 1 shows that the AVE value of all research variables has a value of $>0.5$, which means that the manifest variable representation of the latent construct is quite good.

The construct reliability test was performed by taking into the results account of the composite reliability value and Cronbach's alpha value, where the construct had good reliability if the $\mathrm{CR}$ value was $>0.7$ and the Cronbach's alpha value was > 0.6. The output result from the outer model of the study are shown in Table 3.

Table 3 Cronbach's Coefficient Alpha dan Composite Reability (CR) Value

\begin{tabular}{ccc}
\hline Variables & Cronbach's Coefficient Alpha & Composite Reability (CR) \\
\hline Prophetic Leadership & 0.965 & 0.970 \\
Organizational Commitment & 0.968 & 0.974 \\
Motivation & 0.953 & 0.962 \\
Performance & 0.965 & 0.968 \\
\hline
\end{tabular}

According to Table 2 above, it is known that the Cronbach's Coefficient Alpha> 0.6 and the $\mathrm{CR}$ value> 0.7 so that all variables are declared reliable, meaning that the research model meets the construction reliability.

\section{Inner model analysis (structural model)}

This test is done by evaluating the path coefficient, R2 value, effect size f2, Goodness of Fit Index (GoF), and predictive relevance (Q2).

Evaluation of the path coefficient value can be seen in Table 4. 
Table 4 The Effect of Independent Variables Partially on Dependent Variables

\begin{tabular}{llllll}
\hline & $\begin{array}{l}\text { Original } \\
\text { Sample (O) }\end{array}$ & $\begin{array}{l}\text { Mean } \\
\text { Sample (M) }\end{array}$ & $\begin{array}{l}\text { Deviation } \\
\text { Standart } \\
\text { (STDEV) }\end{array}$ & $\begin{array}{l}\text { T Statistik } \\
\text { (O/STDEV) }\end{array}$ & P Values \\
\hline $\begin{array}{l}\text { Prophetic Leadership } \\
\text { (x1) ->Motivation (y1) }\end{array}$ & 0.422 & 0.409 & 0.129 & 3.261 & 0.001 \\
\hline $\begin{array}{l}\text { Leadership Prophetic } \\
\text { (x1) ->Performance }\end{array}$ & 0.298 & 0.308 & 0.097 & 3.071 & 0.002 \\
(y2) & & & & & \\
\hline $\begin{array}{l}\text { Organizational } \\
\text { Commitment (x2) - }\end{array}$ & 0.438 & 0.450 & 0.128 & 3.415 & 0.001 \\
$>$ Motivation (y1) & & & & & \\
\hline $\begin{array}{l}\text { Organizational } \\
\text { Commitment (x2) -> } \\
\text { Performance (y2) }\end{array}$ & 0.454 & 0.445 & 0.097 & 4.668 & 0.000 \\
\hline $\begin{array}{l}\text { Motivation (y1) -> } \\
\text { Performance (y2) }\end{array}$ & 0.235 & 0.233 & 0.078 & 3.010 & 0.003 \\
\hline
\end{tabular}

Based on Figure 3 and Table 3, the research structural equation is as follows:

1. Motivation $(\mathrm{Y} 1)=0.422 \gamma 1+0.438 \gamma 2$

2. Employee Performance $(\mathrm{Y} 2)=0.298 \gamma 3+0.454 \gamma 4+0.235 \beta$

From above formula it can be concluded:

1. Prophetic leadership has an effect of 0.422 on motivation with a T-Statistic value of 3.261 and P-Values of 0.001 .

2. Prophetic leadership has an effect of 0.298 on performance with a T-Statistic value of 3.071 and a P-Values of 0.002 .

3. Organizational commitment has an effect of 0.438 on motivation with a T-Statistic value of 3.415 and a P-Values of 0.001 .

4. Organizational commitment has an effect of 0.454 on performance with a T-Statistic value of 4.668 and $\mathrm{P}$-Values of 0.000 .

5. Motivation has an effect of 0.235 on performance with a T-Statistic value of 3.010 and P-Values of 0.003 .

\section{Evaluate R2.}

The research results obtained R-squares 0.680 and 0.856 , these results indicate that the structural model is very good. This value means that $68 \%$ of the prophetic leadership variable can be influenced by the motivation variable, $85.6 \%$ of the employee performance variable able to jointly influenced by the competency variable, motivation variable and the organizational commitment variable.

With the R-squares value of 0.680 and 0.856 , the calculated $F$ is obtained from the following calculation:

a. $\mathrm{R}^{2}=0,680(\mathrm{MOT})$

$$
\mathrm{F} \text { count }=\frac{\frac{R^{2}}{(k-1)}}{1-R^{2} /(n-k)}
$$




$$
\begin{aligned}
& \begin{array}{l}
\mathrm{F} \quad \text { count } \quad=\quad \frac{\frac{0.680}{(4-1)}}{1-0,680 /(80-4)} \\
\mathrm{F} \text { count }=0.226 / 0.0042
\end{array} \\
& \mathrm{~F} \text { count }=53.81
\end{aligned}
$$
F
count$$
=\quad \frac{\frac{0.856}{(4-1)}}{1-0,856 /(80-4)}
$$

The calculated $\mathrm{F}$ value in this study is 53.81 and 150.6 , the $\mathrm{F}$ table value at alpha 0.1 is 2.16. it is known that $\mathrm{F}$ count $>\mathrm{F}$ Table (2.16).

The results of the effect size (f square) with Smart PLS version 3.0 are suitable with Table 4

Table 5 effect size $\mathbf{f}^{2}$ Value Result

\begin{tabular}{|c|c|c|c|}
\hline No. & Variable & Score F2 & Notes \\
\hline 1 & Prophetic Leadership (x1)--> Motivation (Y1) & 0,168 & Moderate \\
\hline 2 & Prophetic Leadership (x1)--> Employee Performance (Y2) & $\mathbf{0 , 1 8 1}$ & Moderate \\
\hline 3 & Organizational Commitment (x2)--> Motivation (Y1) & $\mathbf{0 , 1 5 9}$ & Moderate \\
\hline 4 & Organizational Commitment (x2)--> Employee Performance (Y2) & $\mathbf{0 , 3 6 3}$ & High \\
\hline 5 & Motivation (Y1) --> Employee Performance (Y2) & $\mathbf{0 , 1 2 3}$ & Moderate \\
\hline
\end{tabular}

\section{Evaluation results of the Goodness of Fit Index (GoF):}

$\mathrm{GoF}=\sqrt{ }\left(\mathrm{AVE} \times \mathrm{R}^{\wedge} 2\right)$

$\mathrm{GoF}=\sqrt{ }(0.75 \times 0.291)$

$\mathrm{GoF}=\sqrt{ } 0.218$

$\mathrm{GoF}=0.466$

Information :

$\mathrm{AVE}=(0.769+0.768+0.788+0.709) / 4=0.75$

R square $=(0.680 \times 0.856) / 2=0.291$

Based on the GoF evaluation results, it was found that the performance of the measurement model and the structural model as a whole considered to be quite good since the GoF value was more than 0.36 (large scale GoF).

\section{Predictive Relevance Testing (Q2)}

$\mathrm{Q} 2=1-(1-\mathrm{R} 12)(1-\mathrm{R} 22)$

$\mathrm{Q} 2=1-(1-0.680)(1-0.856)$

$\mathrm{Q} 2=1-(0.320)(0.144)$

$\mathrm{Q} 2=1-0.0460$

$\mathrm{Q} 2=0.954$

Based on the above calculations, it was found that the construction model has good predictive ability because the result of $\mathrm{Q}_{2}=0.954$ is greater than 0 , which means that the 
endogenous latent variable has a predictive relevance value $>0$, this means that the exogenous latent variable is able to predict the endogenous variable, namely employee performance.

Table 6 The Effect of Independent Variables Simultaneously on Dependent Variables

\begin{tabular}{|c|c|c|c|c|c|}
\hline & $\begin{array}{c}\mathbf{R} \\
\text { square }\end{array}$ & $\begin{array}{c}\text { F } \\
\text { Statistics }\end{array}$ & $\begin{array}{c}\mathbf{F} \\
\text { Table }\end{array}$ & Alpha & Conclusion \\
\hline $\begin{array}{c}(\mathrm{KP}, \mathrm{KO})-> \\
\mathrm{MOT}\end{array}$ & 0.680 & 53,81 & 2.73 & \multicolumn{2}{|c|}{$\begin{array}{c}0.05 \text { FCount }>\text { FTable } \\
\left(\mathrm{H}_{6} \text { Accepted }\right)\end{array}$} \\
\hline $\begin{array}{c}(\mathrm{KP}, \mathrm{KO}, \\
\mathrm{MOT})- \\
>\mathrm{KK}\end{array}$ & 0.856 & 150,6 & 2.73 & 0.05 & $\begin{array}{c}\text { FCount > FTable } \\
\text { (H7Accepted) }\end{array}$ \\
\hline
\end{tabular}

The results of the above calculations show that the value of $\mathrm{F}$ count 1 in this study is 53.81> F table (2.73) which proves that the variables of Prophetic Leadership, Organizational Commitment simultaneously have a positive and significant effect on motivation. While the value of F count 2 is $150.6>\mathrm{F}$ table (2.73), so that the variables of Prophetic Leadership, Organizational Commitment, and Motivation simultaneously have a positive and significant effect on performance.

\section{Inderect Effect}

The Estimation of indirect effect simultaneously through the addition of a mediating variable between the independent variable and the dependent variable. In this study, the indirect effect was carried out doing an estimate, namely the role of the motivation variable in mediating the influence of the prophetic leadership variable and the organizational commitment variable on the performance variables described in Figure 6 as follows

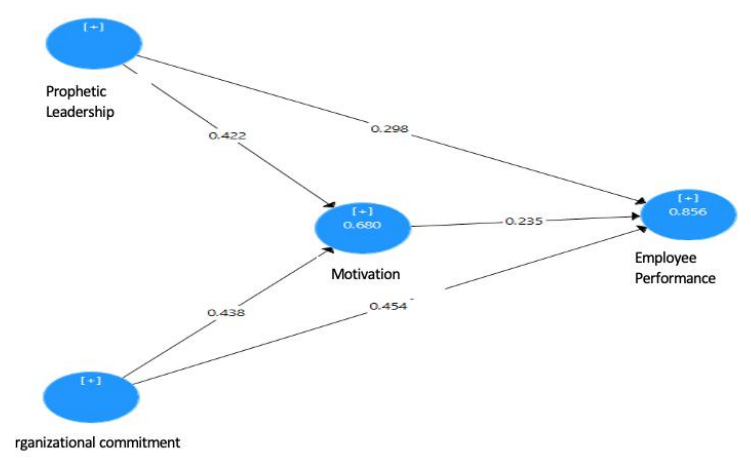

Figure 6 : Testing Model of Indirect Effect with Smart PLS

Figure 6. The value of the indirect effect of prophetic leadership and organizational commitment on performance is as follows:

1) Indirect correlation of prophetic leadership on performance, namely the coefficient value of direct influence of prophetic leadership on motivation multiplied by the coefficient value of direct influence of motivation on performance $\diamond 0.422 \times 0.235=0.239$.

2) The indirect correlation of organizational commitment to performance is the coefficient value of direct influence of organizational commitment to motivation multiplied by the 
coefficient value of direct influence of motivation on performance $\diamond 0.438 \times 0.235=$ 0.247 .

\section{Inter-Dimensional Correlation}

The correlation analysis between dimensions aims to measure the level of relationship between dimensions in variable $\mathrm{X}$ with dimensions in variables $\mathrm{Y} 1$ and $\mathrm{Y} 2$ and dimensions in variable $\mathrm{Y} 1$ with dimensions in variable $\mathrm{Y} 2$. The results of the correlation between dimensions are shown in the table below:

Table 7 Matrix Result of Inter-Dimensional Correlation Variabel

\begin{tabular}{|c|c|c|c|c|c|c|c|c|}
\hline \multirow{2}{*}{ Variable } & \multirow{2}{*}{ Dimension } & \multicolumn{3}{|c|}{ Motivation (Y1) } & \multicolumn{4}{|c|}{ Employee Performance (Y2) } \\
\hline & & Y1.1 & Y1.2 & Y1.3 & Y2.1 & Y2.2 & Y2.3 & Y2.4 \\
\hline \multirow{4}{*}{$\begin{array}{l}\text { Prophetic } \\
\text { Leadership (X1) }\end{array}$} & Shiddiq & 0,719 & 0,634 & $\mathbf{0 , 3 1 2}$ & 0.023 & 0.333 & 0,063 & 0,126 \\
\hline & Ammanah & 0.391 & 0.197 & $\mathbf{0 , 2 7 0}$ & 0.278 & 0.159 & 0,422 & $\mathbf{0 , 1 7 3}$ \\
\hline & Tabligh & 0.548 & 0.401 & $\mathbf{0 , 9 3 2}$ & 0.206 & 0.173 & $\mathbf{0 , 0 3 7}$ & 0,206 \\
\hline & Fathonah & 0,021 & -0.048 & 0,291 & 0,081 & 0,166 & 0,049 & 0,268 \\
\hline \multirow{3}{*}{$\begin{array}{l}\text { Organizational } \\
\text { Commitment (X2) }\end{array}$} & $\begin{array}{l}\text { Affective } \\
\text { Commitment }\end{array}$ & $-0,234$ & 0.272 & 0,760 & 0.140 & $\mathbf{0 , 4 0 2}$ & $\mathbf{0 , 2 9 9}$ & 0.655 \\
\hline & $\begin{array}{l}\text { Continity } \\
\text { Commitment } \\
\end{array}$ & $\mathbf{0 , 5 4 8}$ & 0.422 & 0,824 & 0.126 & $\mathbf{0 , 2 0 4}$ & $\mathbf{0 , 0 2 8}$ & 0.115 \\
\hline & $\begin{array}{l}\text { Normatif } \\
\text { Commitment } \\
\end{array}$ & $\mathbf{0 , 0 1 2}$ & $\mathbf{0 , 3 5 0}$ & 0.251 & 0.816 & 0.138 & $\mathbf{0 , 0 9 0}$ & 0,200 \\
\hline
\end{tabular}

Table 8 Matrix Result of Inter-Dimensional Correlation Variabel

\begin{tabular}{|c|c|c|c|c|c|}
\hline \multirow{2}{*}{ Variable } & \multirow{2}{*}{ Dimension } & \multicolumn{4}{|c|}{ Employee Performance (Y2) } \\
\hline & & Y2.1 & Y2.2 & Y2.3 & Y2.4 \\
\hline \multirow{3}{*}{ Motivation (Y1) } & Need For Achievement & 0,597 & 0,727 & 0,784 & 0,815 \\
\hline & Need For Affiliation & 0.473 & 0.285 & 0,271 & 0,341 \\
\hline & Need For Power & 0,313 & $-0,154$ & 0,282 & 0,374 \\
\hline
\end{tabular}

\section{Inter-Dimensional Correlation Analysis}

From Table 7 and Table 8, the following results are found:

1. In the prophetic leadership variable toward the variable of motivation, the highest correlation dimension is shiddiq toward of need for achievement dimension, amounting to 0.719 . So that the shiddiq dimension in this prophetic leadership variable is needed in every leader in order to become a good role model for his employees.

2. In the prophetic leadership variable toward the performance variable, the highest correlation dimension is prophetic leadership, that is Amanah dimension toward the work 
quality dimension, which is 0.422 . So that the dimensions of work quality and ammanah are needed in every improvement in employee performance.

3. In the variable organizational commitment toward the motivation variable, the most important dimension correlation is the effect of direct continuity commitment to the motivational dimension, amounting to 0.824 . So that the continuity and motivational dimensions in the variable Organizational commitment are needed with high motivation in order to create both sustainable and better performance in work.

4. In the variable organizational commitment toward performance variables, the highest correlation dimension is direct normative commitment to the dimension of work quality, amounting to 0.816 . So that the dimension of normative commitment in the variable of organizational commitment is needed in every increase of organizational commitment, especially in the normative dimension.

5. In the motivation variable on the performance variable, the highest correlation dimension is the need for achievement on the responsibility dimension, amounting to 0.815 . The dimensions of the need for performance in the performance variable are very much needed by every worker who has given good results must be appreciatede hence their performance will be even better in the future.

\section{FINDING AND DISCUSSION}

\section{Prophetic Leadership Affects Motivation (H1)}

The results of the analysis indicate that prophetic leadership affects motivation positively and significantly. These results are in accordance with Ganjar's research. Nugroho and Hafiz (2019) and Fridayanti (2019), that prophetic leadership has a positive and significant effect on motivation.

Based on the correlation between variable dimensions, the shiddiq dimension has the strongest influence on motivation. Management can make shiddiq dimension as a benchmark for increasing employee morale.

\section{Organizational Commitment Affects Motivation (H2)}

The results of the analysis indicate that organizational commitment has a positive and significant effect on motivation. This is in line with the research of Runi I and Mansyur R (2017) and Nurhayati M (2018) which show the results that organizational commitment has a positive and significant effect on work motivation. From the correlation between the variable dimensions, the dimension of continuity has the strongest influence on motivation. This means that every organization always fosters employee motivation on an ongoing basis as part of its needs.

\section{Prophetic Leadership Affects Employee Performance (H3)}

The results of the analysis indicate that prophetic leadership affects employee performance positively and significantly. This is in line with the research by Nurhayati $\mathrm{M}$ (2018) which states that prophetic leadership has a positive effect on job satisfaction, the same thing was also expressed by Sri Arha Lestari (2016) and Abdurrahman (2016) that leadership has a positive effect on employee performance and job satisfaction. Based on the correlation between variable dimensions, the Ammanah dimension has the strongest influence on employee performance. Organizational management, in order to be a good role model for employees. 


\section{Motivation Affects Employee Performance (H4)}

The results of the analysis indicate that motivation affects employee performance positively and significantly. These results are in accordance with the research of Runi I and Mansyur R (2017). Based on the correlation between the variable dimensions, the responsibility dimension has the strongest influence on employee performance. By cultivating a high sense of responsibility in working, it will automatically improve performance.

\section{Motivation Affects Employee Performance (H5)}

The results of the analysis indicate that motivation affects employee performance positively and significantly. This is in accordance with the research of Wardani K (2017). Based on the correlation between the variable dimensions, the dimensions of the need for achievement have the strongest influence on employee performance. This means that every employee needs appreciation for the success or achievement of their performance. By giving appreciation, psychologically will foster enthusiasm in contributing to good performance.

\section{Prophetic leadership and organizational commitment affect motivation (H6)}

The results of the analysis indicate that competence and motivation jointly influence organizational commitment. The result of $\mathrm{R}$ square is 0.680 , meaning that prophetic leadership and organizational commitment affect motivation by $68 \%$, the rest is influenced by other variables. These results are in accordance with the assumption that there is a link between prophetic leadership and organizational commitment together on motivation.

\section{Prophetic leadership, organizational commitment, and motivation affect employee performance (H7)}

The results of the analysis indicate that competency, motivation and organizational commitment jointly influence employee performance, the $\mathrm{R}$ square value is 0.856 means that prophetic leadership, organizational commitment and motivation jointly affect employee performance by $85.6 \%$ and the rest are influenced by other variables.

\section{Motivation Mediates Competence Against Employee Performance (H8)}

The path coefficient value of the direct influence of prophetic leadership on performance is 0.2982 <the path coefficient value of the indirect influence of prophetic leadership on performance is 0.099 and the $\mathrm{p}$ value of the indirect effect of the prophetic leadership variable on performance by mediating the motivation variable is 0.000 with a $t$ value of 5.099. The path coefficient value of direct influence of organizational commitment on performance is 0.4542 <path coefficient value of the indirect effect of training on performance is 0.103 and the $p$ value of the indirect effect of training variables on performance is mediated by the organizational commitment variable of 0.000 with a $t$ value of 5,293. So that the $\mathrm{p}$ value obtained is $<0.05$ and $\mathrm{t}$ statistic $>1.98$, then $\mathrm{H} 0$ is rejected and $\mathrm{H} 8$ is accepted. Thus, it can be concluded that the variables of organizational commitment and motivation have an indirect correlation to performance with the mediation of the motivation variable. This is in line with research by Nurul Qomarianing P Nurul (2016). 


\section{CONCLUSION}

The conclusions of the discussion are: Based on the results of the research and discussion in the previous chapters, some conclusions can be made as follows:

1. Prophetic leadership has a significant positive effect on motivation, with the shiddiq dimension has the strongest influence.

2. Organizational commitment has a significant positive effect on motivation, with the dimension of affective commitment has the strongest influence.

3. Prophetic leadership has a significant positive effect on performance, with the shiddiq dimension has the strongest influence.

4. Organizational commitment has a significant positive effect on performance, with the dimension of affective commitment has the strongest influence.

5. Motivation as a mediator in this study has a significant effect on performance.

6. Prophetic leadership and organizational commitment together have a significant positive effect on motivation.

7. Prophetic leadership, organizational commitment and motivation simultaneously have positive and significant influence on performance.

8. Motivation does not mediate prophetic leadership and organizational commitment on performance

\section{Sugesstions}

1. There needs to build capacity building program in which consist of a management program thoughts and motivation in order employee to have resistant for jobs that require alertness, priority scale, planning, and quick completion.

2. Relating the values of organizational culture, especially the value of cooperation and professionalism, which is passed down into the work culture of employees hence each employee is accustomed to this culture so that values are created in each individual employee. With the escaltion spirit of cooperation for all employees, the performance of PT BPRS Al Salam will increase as well.

3. To increase employee morale, it is necessary to create a routine motivation program for employees to invite external parties in the form of motivators or coaching or internal training aimed at fostering morale from within employees.

4. Organizational commitment needs to be improved, especially in relation to engagement / loyalty. Management / leadership of the company must be an example of a good role model so that employees can feel the presence of the leaders, especially if there are problems or obstacles as a company problem solver.

5. The leadership or management of the company need to perform continuous monitoring or review the performance as well as a means of counseling from the Supervisor or Management so that each employee will continue to make changes and improvements in order to foster integrity, enthusiasm, responsibility and to perform better.

6. In this study, the focus is on employee performance as the main factor in BPRS Al Salaam. Further research in order to explore other factors and to increase the number of respondents to make it more valid.

7. Future research can also scoop deeper into other factors that are not available in this study, there may be other variables that affect other performance. His further research can develop prophetic leadership variable, on performance is mediated by motivation as a mediator and organizational commitment is not mediated by motivation on performance found in this study will open the possibility of other influences of motivation on other variables. 


\section{REFERENCE}

Allen and Meyer. (2011). The Measurement and Antecedents of Affective, Contintinuance and Normative Commitment to Organitazion. PT Elex Media Komputindo,Jakarta

Antonio, Budiharto dan Himam (2007). Muhammad SAW : The Super leader manager. Jakarta:proLmcente.

Nugroho S and Hafidz Aima (2019). The influence of Transpormational Leadership and compentation on the performance employee of PT. X. Tesis. Universitas Mercu Buana.Jakarta.

Fridayanti F (2019). The effect of transparency and compensation leadership on work motivation and its implementasi on vocational employee performance. Tesis. Universitas Mercu Buana.Jakarta.

Runi Ishak dan Mansyur Ramli (2017). The influence of discipline, commitment, motivation on employee performance at the vesse traffic office in makassar, south sulawesi. IQSR Journal of business and management (IQSR-JBM) Vol.19,N0.7.

Nurhayati Mafizatun (2018). The influence of prohetic leadership on organizational commitment mediated by organizational beliefs and perceptions of organizational politics, case studies on management Nahdatul Ulama DKI Jakarta. Disertasi. Universitas Brawijaya.Malang.

Mangkunegara, Anwar Prabu (2011). Human Resource for Management for companies. Bandung :Remaja Rosdakarya.

Thoha, Mifta. (2012). Organizational Behavior. Basic Concepts and Applications. Rajawali Pers.Jakarta.

Qomarianing P Nurul (2016). The Influence of organizational commitment on employee performance through motivation as an intervening variable for employees of the finance and accounting department of Yogyakarta State University. Skripsi. Universitas Negeri Yogyakarta. Yogyakarta.

Wardani Kusuma. (2017) Analysis of the influence of performance and motivation on the performance of adimistrative bureau employees. Tesis. Universitas Sanata Dharma.

Zuhdi (2014) Leadership Transpormational Prophetic. Prenadamedia Group.Jakarta. 